\title{
The Cultural Genocide in Australia: A Case Study of the Forced Removal of Aborigine Children from 1912-1962
}

\author{
Nuriyeni Kartika Bintarsari $1^{1, *}$ \\ ${ }^{1}$ Universitas Jenderal Soedirman, Purwokerto, Indonesia
}

\begin{abstract}
This paper will discuss the Forced Removal Policy of Aborigine children in Australia from 1912 to 1962. The Forced Removal Policy is a Government sponsored policy to forcibly removed Aborigine children from their parent's homes and get them educated in white people households and institutions. There was a people's movement in Sydney, Australia, and London, England- in 1998- to bring about "Sorry Books." Australia's "Sorry Books" was a movement initiated by the advocacy organization Australian for Native Title (ANT) to address the failure of The Australian government in making proper apologies toward the Aboriginal and Torres Strait Islander population. The objective of this paper is to examine the extent of cultural genocide imposed by the Australian government towards its Aborigine population in the past and its modern-day implication. This paper is the result of qualitative research using literature reviews of relevant materials. The effect of the study is in highlighting mainly two things. First, the debate on the genocidal intention of the policy itself is still ongoing. Secondly, to discuss the effect of past government policies in forming the shape of national identities, in this case, the relations between the Australian government and its Aborigine population.
\end{abstract}

\section{Introduction and Literary Review}

Australia has experienced the darkest period of genocide during the British colonization. The Forced Removal Policy of Aborigine children resulted in the massive resentment of Aborigine community toward Australian government. In 1998, there was a people movement in Sydney, Australia and London, England, to bring about Sorry Books" [1]. The Sorry Books was a movement initiated by an advocacy organization, Australian for Native Title (ANT), to address the failure of the Australian government in making proper apologies toward the Aboriginal and Torres Strait Islander population. The Sorry Books thus "functioning not unlike guest or condolence books, they generated more than half a million signatures and a great variety of apologies to the Aboriginal and Torres Strait Islander population" [1]. These books served as a token of apology from the Australian non-Indigenous people for all injustices suffered by the Indigenous people, during the Colonization Period of the European settlement on the Australian continent, which begun

\footnotetext{
*Corresponding author: nuriyeni@gmail.com
} 
on January 28, 1788.

A Polish lawyer named Raphael Lemkin was the first person to formulate the definition of genocide. He coined the term using the ancient Greek Word genos (race, tribe) and cide or killing in Latin word" [1]. According to Lemkin, genocide means "the destruction of a nation or of an ethnic group" [1]. Genocide in its legal definition as stated in the United Nations Convention on the Prevention and Punishment of the Crime of Genocide (hereafter called UNCG) is defined as : "any of the following acts committed with the intent to destroy, in whole or on part, a national, ethnical, racial or religious group, as such: a) Killing members of the group; b) Causing serious bodily or mental harm to members of the group; c) Deliberately inflicting on the group conditions of life calculated to bring about its physical destruction in whole or in part; d) Imposing measures intended to prevent births within the group; e) Forcibly transferring children of the group to another group" [2].

Genocide can be analyzed based on the action itself and the intention. Schabas explains, "The crime of genocide comprises both a physical element (actus reus) and a mental element (mens rea)" [3]. Schabas further noted that the legal definition of the 1948 Genocide Convention describes the separation of actions and intentions. In his article, Schabas examines, "The initial phrase or chapeau of article II addresses the mens rea of the crime of genocide...the five subparagraphs of article II list the criminal acts or actus reus" [3]. Ian Kershaw made a similar assessment on the intention and action of genocide in the case of Hitler's Holocaust. Kershaw argues on the notion between "Intentionalism" and "Structuralism", in which "Intentionalism" refers to "approach proceeds from the assumption that Hitler himself, from a very early date seriously contemplated, pursued as a main aim, and strived unshakably to accomplish the physical annihilation of the Jews" [4]. The main points of Intentionalism are the aims and intentions of the perpetrators that mainly count regarding genocide. On the other hand, Structuralism refers to "“" [a] type of approach "[that] lays emphasis upon the unsystematic and improvised shaping..." [it] emerged itself as an ad hoc "solution" to massive, and self-induced, administrative problems of the regime" [4]. Structuralism examines that in most genocide cases, they were not intentionally genocidal in its formulation but rather as excess of some government's policies.

The Forced Removal Policy of Aborigine and half-caste Aborigine children is both intentional and systematic genocide, because the policy makers wanted to absorb and change the ethnic identities in those children through systematic policies in order to "breeding out the color of the Aborigines" [5]. Manne highlighted this policy as "the biological absorption into the white of the half-caste population through a state-engineered program of encouraged miscegenation" [6]. Encouraged miscegenation is common in the marriage between white men and half-caste women and another strategy was to encourage the sterilization of all half-castes, although the latter policy gained limited support from the Australian White Settlers. Based on the general definition of genocide, Krieken offers definition of Cultural genocide as "the destruction by brutal means of the specific characteristic of the group" [7]. Krieken also wrote that cultural genocide was more than forced assimilation, but also was "aimed at the rapid and complete disappearance of the cultural, moral and religious life of a group of human beings" [7]. Cultural genocide in Australia was aimed solely at Aborigine and half-caste children, in order to assimilate them into European upbringing and European civilization. Nersessian assessed cultural genocide to

"Extends beyond attacks upon the physical and/ or biological elements of a group and seek to eliminate its wider institution...often includes the abolition of a group's language, restrictions upon its traditional practices and ways, the destruction of religious institutions and objects, the persecution of clergy members, and attacks on academics 
and intellectuals" [18].

In whatever form, whether it is physical or non-physical, genocide together with crimes against humanity and war crimes are part of the international atrocity crimes. In the $18^{\text {th }}$ century, Aborigines were targeted and murdered on the basis of their race and perception that they hindered the progress of civilization in parts of Australia, such as in Queensland, Victoria and New South Wales. Dirk Moses argued "the British colonization of Australia was objectively and inherently ethnocidal and fatal for Aborigines, and potentially genocidal" [19]. It could be the same perception that led the Europeans to massacre the Aborigines, because of fear of something different and strange. This memory is what collectively shaped the behaviors of the Aborigine people toward modern-day Australian government. Halbwachs argues, "The individual calls recollections to mind by relying on the frameworks of social memory" [10]. Social memory is a term that recalls the collection of memories that Halbwachs explains as "retains from the past only what still lives or is capable of living in the consciousness of the next groups keeping the memory alive" [11]. Social memory is living within a particular society, since society is "like a thread that is made from a series of animal or vegetable fibers intertwined at regular intervals" [11]. This thread of community thus reiterates and recounts memories from the previous generations to the younger generations which created a specific collective memory of Aborigine community in Australia. The forced removal policy of Aborigine children resulted in the traumatic experience, evident in "a three-year longitudinal study undertaken in Melbourne during the mid-1980s revealed the numerous differences between respondents removed in childhood $(33 \%)$ and those who were raised by their families or in their communities $(67 \%)$. Those removed were developing symptoms such as: less likely to have undertaken a post-secondary education; much less likely to have stable living conditions and more likely to be geographically mobile; less likely to be in a stable, confiding relationship with a partner; twice as likely to report having been arrested by police and having been convicted of an offence; less likely to have a strong sense of their Aboriginal cultural identity, more likely to have discovered their Aboriginality later in life and less likely to know about their Aboriginal cultural traditions (Dr Jane McKendrick, Victorian Aboriginal Mental Health Network, submission 310 page 22)" [12].

The study shows that the extent of the Forced Removal Policy has affected the later generations and descendants of the victims. Largely, the practice shaped the way the Aborigine community perceived themselves and perceived the non-Indigenous people of Australia, which in the end resulted in the poor conditions of that particular community.

\section{The Forced Removal of Aborigine Children (1912-1962)}

The Australia's Sorry Books movement is a nation-wide movement. Before the movement, there was an inquiry established in 1995 by the former Attorney-General, the Hon. Michael Lavarch MP who focuses "in response to increasing concern among key Indigenous agencies and communities that the general public's ignorance of the history of forcible removal was hindering the recognition of the needs of its victims and their families and the provision of services" [20]. In 1997, the Australian Council of Human Rights produced a report entitled Bringing Them Home (BTH). One of the report's objectives was to "trace the past laws, practices and policies which resulted in the separation of Aboriginal and Torres Strait Islander children from their families by compulsion, duress or undue influence, and the effects of those laws, practices and policies" [21]. Indigenous children have been forcibly separated from their families and communities since 1840 as part of government's policy, which began to reach its peak in the first part of the 20th century. One of the prominent reasons the Colonial government targeted the Aborigine children was 
because "... the greatest advantage of young Aboriginal servants was that they came cheap and were never paid beyond the provision of variable quantities of food and clothing. As a result any European on or near the frontier, quite regardless of their own circumstances, could acquire and maintain a personal servant." Governments and missionaries also targeted Indigenous children for removal from their families. Their motives were to "inculcate European values and work habits in children, who would then be employed in service to the colonial settlers" [12]. Enforced slavery resulted in the sexual interactions mainly between Aborigine females and European men. These interactions consequently produced mixed-race children, often referred to as the "half-caste children".

These children later became the main target of the forced removal policy, as they were perceived to be easier to educate and assimilate into the European civilization because of their "white" blood. Robert Manne explains the history of the forced removal policy as "according to the old Aboriginal Act of 1865, the police in Queensland were able to bring any Aboriginal or half-caste child before a magistrates' court, to charge them with being neglected simply on the evidence that their mother was an Aborigine" [12]. Those children thus "transferred to a reformatory or what was called, at the time, an Industrial School. Moreover, according to the new Aboriginal Act of 1897, the Prosecutors were able to remove, under warrant from the Home Minister, any Aboriginal or half-caste Aboriginal adult or child to any location in the state" [12].

The BTH mentioned that "In 1814 Governor Macquarie funded the first school for Aboriginal children. Its novelty was an initial attraction for Indigenous families but within a few years it evoked a hostile response when it became apparent that its purpose was to distance the children from their families and communities" [12]. In the BTH report, there are testimonials of traumatic events on separation between parents and their children and separation between siblings that had to go to separate foster homes, a policy conducted mainly in Western Australia, Queensland, and the Northern Territory during the period 1912-1962. Dirk Moses, a genocide scholar, elaborated the argument regarding whether the forced removal of children policy was genocidal in its intention. Moses examined the debate as described below:

"Many Aborigines believe that they were the object of genocidal policies, and historians on the Left tend to agree with them. Conservative commentators and the current federal government, for their part, vehemently reject this position. There is an unfortunate if understandable tendency in the former camp to comb the Australian past in search of evidence of genocide, and a proclivity to interpret any such evidence in the worst light. The latter camp do not deny the killings, but it absolves the colonial and national governments of responsibility, and it insists that while the policies of child removal may have been misguided by today's standards, they were well intentioned" [13].

\section{The Reconciliation Process of the Stolen Generation}

The Aborigine and Torres Strait Island people demanded a national apology from the government for the past genocidal policy. They refused to forget the past and were angry at the failure of the Prime Minister John Howard to formally apologize to the Aborigine community in 1997. In the discussion of cultural genocide in Australia, reconciliation and restitution for the victims are very crucial. Meierhenrich argues that reconciliation is "the accommodation of former adversaries through mutually conciliatory means, requiring both forgiveness and mercy" [9]. In his article Meierhenrich explains, "mercy" is "the extension of an act of compassion to the undeserving person who has committed an unjustified and non-excused moral injury." Mercy and forgiveness are inherent parts in the reconciliation process, as reconciliation is one of the most effective ways for the Indigenous and non- 
Indigenous people in Australia to continue to live in co-existence without forgetting the past.

The Australian government must address the cultural trauma endured by the Indigenous community. Cultural genocide that leads to cultural trauma can be remedied if there is enough remembrance of this notion. In Australia, the coverage of the Sorry Books has certainly encouraged people to formulate a national apology toward Aborigine and Torres Strait Island community.

\section{Conclusion}

The debate on the genocidal intention of the policy itself is still ongoing. One camp argues that it is indeed genocidal, because in removing Aborigine children from their families, it means the disruption on the transfer of knowledge of their specific cultures and way of life. The opposing camp argues that although by modern standards the policy was considered inhuman and genocidal, it was formed out of well intention in the well-being of that children, especially the half-caste Aborigine population. Only by openly acknowledging and genuinely trying to repair the consequences of their past genocide policy, can reconciliation be achieved in modern-day Australia.

\section{References}

1. M. Jens. Genocide: A Reader/GR (Oxford University Press, Oxford, 2014).

2. The Legal Definition (United Nations Convention on the Prevention and Punishment of the Crime of Genocide). In GR. (2014)

3. W. A. Schabas, Actus Reus and Mens Rea of Genocide, In GR. (2014)

4. I. Kershaw, Explaining the Holocaust: Intentionalism versus Structuralism, In GR, (2014)

5. R. Manne, Aboriginal Child Removal and Half-Castes in Australia, In GR. (2014)

6. D. Stone (ed), The Historiography of Genocide. (Palgrave Macmillan, Hampshire, 2008)

7. The Historiography of Genocide, (2008)

8. D. Nersessian, Cultural Genocide, In GR. (2014)

9. D. A. Moses, The Origins of the Genocidal Moment in the Colonization of Australia, In GR, (2014)

10. M. Rossington, A. Whitehead. Theories of Memory: A Reader. (Johns Hopkins University Press, Baltimore, 2007)

11. Theories of Memory: A Reader, (2007)

12. Bringing Them Home: Report of the National Inquiry into the Separation of Aboriginal and Torres Strait Islander Children from Their Families (BTH). (1997) Available at: https://www.humanrights.gov.au/our-work/aboriginal-and-torres-strait-islander-socialjustice/publications/bringing-them-home-stolen

13. Meierhenrich, Jens. What Role for Reconciliation, In GR. 2014) 